\title{
Improving Student's Critical Thinking Through Technology At Historically Black Institutions
}

\author{
Qingxia Li \\ Department of Mathematics and Computer Science Fisk University, \\ Nashville, Tennessee, USA \\ Gloria Payne \\ Department of Natural Sciences Elizabeth City State University, \\ Elizabeth City, NC, USA
}

URL:http://dx.doi.org/10.19044/ejes.v3no3a2

\begin{abstract}
This study examines the differences in student's critical thinking ability through the Watson-Glaser Online Assessment software in a pretestposttest setting. There is a noticeable increase in the categories of Recognize Assumptions and Evaluate Arguments and a relatively large decrease in the category of Draw Conclusions. In general, students from Non-STEM majors benefits more from teaching with technology than those in STEM majors.
\end{abstract}

Keywords: Watson Glaser Online Assessment, Critical Thinking, Recognize Assumption, Evaluate Argument, Draw Conclusion

\section{Introduction}

Critical thinking is one of the ultimate goals in education with most valued outcomes. Critical thinking has many definitions. John Dewey (Dewey, 1910) is among the first few educational leaders who proposed that a curriculum with integrated thinking skills would benefit both the students and the entire learning community. McPeck (McPeck, 1982) recognized that certain aspects of problem solving requires critical thinking which can be treated as a skepticism about a subject or field. According to Beyer (1995), critical thinking means making clear, reasoned judgements. During the process of critical thinking, ideas should be reasoned and well thought out/judged. Critical thinking is the ability to integrate many different ideas to come up with a unique solution to solve a real life problems. In mathematics, critical thinking can be either an analysis or a synthesis. In algebra, one needs to break the work into several parts or steps to solve it, while geometry requires one to combine several elements or formulas together to solve the problem. While Reichenbach (Reichenbach, 2000) defines critical thinking 
as a process of interpreting, analyzing, evaluating, and synthesizing information to form a good understanding, judgement, or solution. Simply acquisition of skills are not enough to meet with the demands in the development of our society and it requires us to think critically and solve a variety of complicated problems. Dewey (Dewey, 1910) states that "if we teach today as we taught yesterday, we rob our children of tomorrow". Many technological tools are constructed to better integrate the teaching techniques in today's classrooms and prepare our students to be critical thinkers in the future.

Once students are able to think critically, they will consider the criteria to make thoughtful decisions or judgments about what to do (Paul, 2012). That is to say, students will not simply guess for the correct answer or apply a formula without thinking its relevance. For instance, rather than directing students to solve an assigned problem step by step with a fixed strategy, the teacher works with them to choose the most appropriate strategy based on the criteria suitable for solving the problems. Students in STEM disciplines (Allen, 1981) often experience difficulties as a result of their inability to see that multiple interpretations of the same data can coexist. Understanding the different stages of thinking will help instructors in these fields to choose the most appropriate way of presenting the course content so that students can make the transition from one stage of thinking to the next smoothly. The instructors should distinguish between an idea and the name of that idea, between facts and conjectures, and be aware of student's thinking process. Aarons (Aarons, 1985) especially discussed why one should care about critical thinking, especially among American students, and how to increase or decrease student's critical thinking ability.

However, technology (Brouwer, 1996) is widely used as a means of improving the quality of teaching and learning. Moll and Allenn (Moll and Allen, 1982) uses video and discussion in class to enable students to derive concepts from the collected data, apply concepts in real life examples and practice scientific processes in a biology class at West Virginia University. They used a pretest/posttest to measure the difference in students' critical thinking skills pretest/posttest. The Reason! Project (Gebler, 2001) at the University of Melbourne has developed the Reason!Able software as part of a general method aimed at enhancing critical thinking skills. They found a consensus around the unsurprising idea that critical thinking skills improve with practice by integrating technology in teaching. Students using Reason!Able appear to make dramatic gains.

The Reason! Project (Gebler, 2001) at the University of Melbourne has developed the Reason!Able software as part of a general method aimed at enhancing critical thinking skills. Rather than tinkering with existing methods, they are building afresh from solid foundations in cognitive 
science. They found a consensus around the unsurprising idea that cognitive skills, like other skills, improve with practice which should be motivated, guided, scaffolded, graduated and providing feedback. Students using Reason!Able appear to make dramatic gains.

This project is to examine the theoretical foundations of critical thinking in higher education and how they can be applied to new opportunities through the use of technology. The Elizabeth City State University-Minority Science and Engineering Improvement Program (ECSU-MSEIP) project addresses the growing shortage of qualified and competent STEM majors by strengthening course curricula through the infusion of critical thinking through technology (CTTT). The MSEIP Project recruited 17 faculty members from a total of ten institutions, consisting of seven Historically Black Colleges and Universities/Minority Institutions, one community college, one women's college, and one tribal college for faculty development and training in the use of "Critical Thinking through Technology" (CTTT) strategies in teaching STEM courses. The majority of students from these institutions come from socially, economically, culturally and academically disadvantaged backgrounds, and qualify for the Pell Grant and other financial assistance. Underrepresented minorities represent only a minute fraction of the population of qualified scientists and engineers in STEM disciplines in the United States.

Thus, the STEM Programs in these institutions provided a national advantage by integrating technology in classroom to potential STEM majors. The ultimate goal of this project was to address the growing shortage of qualified and competent STEM majors by strengthening course curricula through the infusion of critical thinking through technology.

\section{Methodology}

Design. This project used a pretest and posttest of the critical thinking test from the Watson-Glaser Online Assessment to measure the difference of student's critical thinking ability. The Watson-Glaser ${ }^{\mathrm{TM}}$ Critical Thinking Appraisal is the most widely used tool for selecting great managers and developing future leaders. Developed in 1925, the Watson-Glaser has been the premier tool for evaluating the cognitive ability of professionals. The Critical Thinking Test is a quick 40-item, multiple test with many reporting options. It is divided into three categories: Recognize Assumptions (12 questions), Evaluate Arguments (12 questions), and Draw Conclusions (16 questions) that assess student's critical thinking ability in the developmental mathematics courses.

Data Analysis. The following sections summarize the results of the Pretest and Posttests towards critical thinking that were administered to college students at the beginning and the end of Spring 2014. The 
participating institutions include Albemarle College, Bennett College, Bluefield State College, Elizabeth City State University, Hampton University, Shaw University, Lincoln University, West Virginia State University, and Virginia Union University. The targeted courses in this project include Mathematics, Physics, Biology and Computer Science. Of all student participants, 387 students had valid critical thinking pretest scores, and 254 students completed the posttest.

\section{Section 2.1: Comparison of overall Performance of students on Critical Thinking Pretest and Posttest}

Across all students taking the Pretest and Posttest, the number of correct answers had a fairly normal distribution (see Figure 1). The lowest score of the pretest was 0 (3 students) and the highest score was 35 (1 student), while the posttest had the lowest score of 6 (2 students) and the highest score of 38 (1 student). In the posttest, the percent of students who got 6 to 10 correct answers was extremely low (0.6\%) compared with the pretest. Approximately $16 \%$ of students scored 26 or better in the posttest and only $11 \%$ did in the pretest. Although there is no noticeable difference between pretest mean and posttest mean, but the distribution of the posttest did change from a fairly normal distribution to approximately right-skewed distribution. It showed that the majority of student did benefit from the teaching with technology. In general, as shown in Table 1, students performed slightly better in the category of Evaluate Arguments than the other two categories: Recognize Assumptions and Draw Conclusions.

Figure 1. Distribution of the Pretest and Posttest scores for all students.

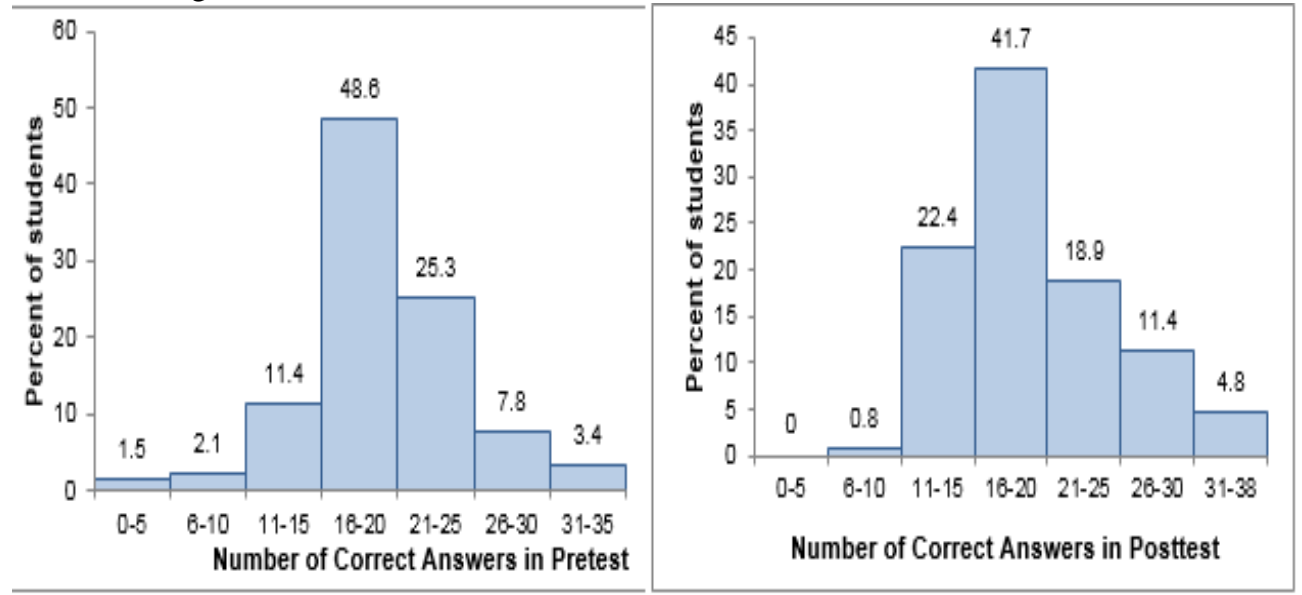


Table 1: Five number summary of the Critical Thinking Pretest

\begin{tabular}{|c|c|c|c|c|c|c|}
\hline \multicolumn{5}{|c|}{ Five-Number Summary of total correct Answers (40) } & \multirow{2}{*}{ Mean } & \multirow{2}{*}{$\begin{array}{l}\text { Standard } \\
\text { deviation }\end{array}$} \\
\hline Minimum & $\mathbf{1}^{\text {st }}$ Quartile & Median & $3^{\text {rd }}$ Quartile & Maximum & & \\
\hline 0 & 17 & 19 & 22 & 35 & $\begin{array}{c}19.553 \\
(48.9 \%) \\
\end{array}$ & 5.17 \\
\hline \multicolumn{5}{|c|}{ Five-Number Summary of Recognize Assumptions (RA) (12) } & \multirow{2}{*}{ Mean } & \multirow{2}{*}{$\begin{array}{l}\text { Standard } \\
\text { deviation }\end{array}$} \\
\hline Minimum & $\mathbf{1}^{\text {st }}$ Quartile & Median & $3^{\text {rd }}$ Quartile & Maximum & & \\
\hline 0 & 4 & 5 & 7 & 12 & $\begin{array}{c}5.45 \\
(45.4 \%) \\
\end{array}$ & 2.62 \\
\hline \multicolumn{5}{|c|}{ Five-Number Summary of Evaluate Arguments (EA) (12) } & \multirow{2}{*}{ Mean } & \multirow{2}{*}{$\begin{array}{l}\text { Standard } \\
\text { deviation }\end{array}$} \\
\hline Minimum & $1^{\text {st }}$ Quartile & Median & $3^{\text {rd }}$ Quartile & Maximum & & \\
\hline 0 & 5 & 7 & 8 & 11 & $\begin{array}{c}6.55 \\
(54.6 \%)\end{array}$ & 1.96 \\
\hline \multicolumn{5}{|c|}{ Five-Number Summary of Draw Conclusions (DC) (16) } & \multirow{2}{*}{ Mean } & \multirow{2}{*}{$\begin{array}{l}\text { Standard } \\
\text { deviation }\end{array}$} \\
\hline Minimum & $\mathbf{1}^{\text {st }}$ Quartile & Median & $3^{\text {rd }}$ Quartile & Maximum & & \\
\hline 0 & 6 & 7 & 9 & 16 & $\begin{array}{c}7.55 \\
(47.2 \%)\end{array}$ & 2.71 \\
\hline
\end{tabular}

Table 2: Five number summary of the Critical Thinking Posttest

\begin{tabular}{|c|c|c|c|c|c|c|}
\hline \multicolumn{5}{|c|}{ Five-Number Summary of Posttest (40) } & \multirow{2}{*}{ Mean } & \multirow{2}{*}{$\begin{array}{l}\text { Standard } \\
\text { deviation }\end{array}$} \\
\hline Minimum & $\mathbf{1}^{\text {st }}$ Quartile & Median & $3^{\text {rd }}$ Quartile & Maximum & & \\
\hline 0 & 16 & 19 & 22 & 38 & $\begin{array}{c}19.681 \\
(49.2 \%) \\
\end{array}$ & 5.25 \\
\hline \multicolumn{5}{|c|}{ Five-Number Summary of Recognize Assumptions (12) } & \multirow{2}{*}{ Mean } & \multirow{2}{*}{$\begin{array}{l}\text { Standard } \\
\text { deviation }\end{array}$} \\
\hline Minimum & $1^{\text {st }}$ Quartile & Median & $3^{\text {rd }}$ Quartile & Maximum & & \\
\hline 1 & 4 & 6 & 8 & 12 & $\begin{array}{c}5.945 \\
(49.5 \%)\end{array}$ & 2.66 \\
\hline \multicolumn{5}{|c|}{ Five-Number Summary of Evaluate Arguments (12) } & \multirow{2}{*}{ Mean } & \multirow{2}{*}{$\begin{array}{l}\text { Standard } \\
\text { deviation }\end{array}$} \\
\hline Minimum & $1^{\text {st }}$ Quartile & Median & $3^{\text {rd }}$ Quartile & Maximum & & \\
\hline 1 & 6 & 8 & 9 & 12 & $\begin{array}{c}7.72 \\
(64.3 \%) \\
\end{array}$ & 2.26 \\
\hline \multicolumn{5}{|c|}{ Five-Number Summary of Draw Conclusions (16) } & \multirow{2}{*}{ Mean } & \multirow{2}{*}{$\begin{array}{l}\text { Standard } \\
\text { deviation }\end{array}$} \\
\hline Minimum & $1^{\text {st }}$ Quartile & Median & $3^{\text {rd }}$ Quartile & Maximum & & \\
\hline 1 & 4 & 6 & 7 & 15 & $\begin{array}{c}6.02 \\
(37.6 \%) \\
\end{array}$ & 2.42 \\
\hline
\end{tabular}

Comparison of Pretest and Posttest. Table 1 shows that the mean of total correct answers in the posttest is slightly higher than that of the pretest. Comparing the Pretest and Posttest of each category, there is a $4.1 \%$ and 9.7\% increase in the categories of Recognize Assumptions and Evaluate Arguments and a 9.6\% decrease in the category of Draw Conclusion. In the five number summary of categories: Recognize Assumption and Evaluate Argument, students typically got one more correct answers in the posttest than the pretest. However, students in general missed two more questions in the category of Draw Conclusions. 
Discussion. Overall, there is no noticeable difference between the total number of correct answers in Pretest and Posttests. However, there is a large increase in the category if Evaluate Argument and relatively small increase in Recognize Assumption. However, a huge decrease occurs in the category of Draw Conclusion comparing the Posttest with the Pretest. Integrating technology in teaching helped students to recognize assumptions and evaluate arguments. As shown in literatures (Brouwer, 1996; Moll and Allen, 1982; Gebler, 2001), using technology improved student's ability in deriving and applying concepts as well as practicing scientific processes, which were in the category of recognizing assumptions and evaluating arguments. However, no research showed an effective way to increase student's ability in drawing conclusions.

\section{Section 2.2: Comparison of STEM and Non-STEM Majors in Pretests and Posttests}

Comparison of Pretest Scores and Posttest Scores for STEM and Non-STEM Majors. In table 3, STEM ${ }^{1}$ represents pretest for STEM majors and NonSTEM ${ }^{1}$ stands for pretest of Non -STEM majors. STEM ${ }^{2}$ and NonSTEM $^{2}$ are posttests for STEM and Non-STEM majors respectively. In general, students from Science, Technology, Engineering, and Mathematics (STEM) did slightly better than students in Non-STEM disciplines in both Pretest and Posttest. This is reasonable because students in STEM majors are typically more knowledgeable with technology software than Non-STEM students. For all disciplines, there are noticeably increase in both the categories of Recognize Assumptions and Evaluate Arguments, but a relatively large decrease in the category of Draw Conclusions. Comparing the pretest mean and posttest mean, STEM majors has a slight decrease while Non-STEM majors has a slight increase. Looking at the five number summary of the pretest and posttest, STEM majors averagely got one more correct answer than Non-STEM majors for class median and 3 more correct answers for the third Quartile.

Table 3: Summary of Pretests and Posttests for STEM and Non-STEM Majors.

\begin{tabular}{|lccccll|}
\hline \multicolumn{2}{|l}{ Five-Number Summary of Total Pretest-Posttest (40) } & & Mean & $\begin{array}{l}\text { Standard } \\
\text { deviation }\end{array}$ \\
\cline { 1 - 5 } & $\begin{array}{l}\mathbf{1}^{\text {st }} \\
\text { Quartile }\end{array}$ & Median & $\begin{array}{c}\mathbf{3}^{\text {rd }} \\
\text { Quartile }\end{array}$ & Max & & \\
\hline $\begin{array}{l}\text { STEM }^{1} \\
10\end{array}$ & 17.75 & 20 & 24 & 35 & $\begin{array}{l}20.98 \\
(52.45 \%)\end{array}$ & 4.98 \\
\hline $\begin{array}{l}\text { Non-STEM } \\
0\end{array}$ & 17 & 19 & 21 & 32 & $\begin{array}{l}18.75 \\
(46.88 \%)\end{array}$ & 5.32 \\
\hline $\begin{array}{l}\text { STEM }^{2} \\
11\end{array}$ & 16 & 20 & 24.5 & 38 & $\begin{array}{l}20.61 \\
(51.53 \%)\end{array}$ & 5.81 \\
\hline $\begin{array}{l}\text { Non-STEM } \\
9\end{array}$ & 16 & 19 & 21 & 37 & $\begin{array}{l}19.05 \\
(47.63 \%)\end{array}$ & 4.83 \\
\hline
\end{tabular}




\begin{tabular}{|c|c|c|c|c|c|c|}
\hline \multicolumn{5}{|c|}{ Five-Number Summary of RA-Pretest -Posttest (12) } & \multirow[b]{2}{*}{ Mean } & \multirow{2}{*}{$\begin{array}{l}\text { Standard } \\
\text { deviation }\end{array}$} \\
\hline Min & $\begin{array}{l}\mathbf{1}^{\text {st }} \\
\text { Quartile }\end{array}$ & Median & $\begin{array}{c}3^{\text {rd }} \\
\text { Quartile }\end{array}$ & Max & & \\
\hline $\begin{array}{l}\text { STEM }^{1} \\
0\end{array}$ & 3 & 5 & 8 & 12 & $\begin{array}{l}5.52 \\
(46 \%)\end{array}$ & 2.84 \\
\hline $\begin{array}{l}\text { Non-STEM }{ }^{1} \\
0\end{array}$ & 4 & 5 & 7 & 12 & $\begin{array}{l}5.32 \\
(44.33 \%) \\
\end{array}$ & 2.54 \\
\hline $\begin{array}{l}\text { STEM }^{2} \\
1\end{array}$ & 4 & 6 & 9 & 12 & $\begin{array}{l}6.32 \\
(52.67 \%)\end{array}$ & 2.82 \\
\hline $\begin{array}{l}\text { NonSTEM }^{2} \\
1\end{array}$ & 4 & 5 & 7.5 & 11 & $\begin{array}{l}5.72 \\
(47.67 \%) \\
\end{array}$ & 2.55 \\
\hline
\end{tabular}

\begin{tabular}{|c|c|c|c|c|c|c|}
\hline \multirow{3}{*}{ (12) } & \multirow{2}{*}{\multicolumn{4}{|c|}{ Five-Number Summary of EA-Pretest-Posttest }} & \multirow{3}{*}{ Mean } & \multirow{3}{*}{$\begin{array}{l}\text { Standard } \\
\text { deviation }\end{array}$} \\
\hline & & & & & & \\
\hline & $\begin{array}{l}\mathbf{1}^{\text {st }} \\
\text { Quartile }\end{array}$ & Median & $\begin{array}{c}3^{\text {rd }} \\
\text { Quartile }\end{array}$ & Max & & \\
\hline $\begin{array}{l}\text { STEM }^{1} \\
2\end{array}$ & 6 & 7 & 8 & 11 & $\begin{array}{l}7.09 \\
(59.08 \%)\end{array}$ & 1.72 \\
\hline $\begin{array}{l}\text { Non-STEM }^{1} \\
0\end{array}$ & 5 & 6 & 8 & 11 & $\begin{array}{l}6.24 \\
(52 \%)\end{array}$ & 2.02 \\
\hline $\begin{array}{l}\text { STEM }^{2} \\
1\end{array}$ & 6 & 8 & 10 & 12 & $\begin{array}{l}8.02 \\
(66.83 \%)\end{array}$ & 2.34 \\
\hline $\begin{array}{l}\text { NonSTEM } \\
1\end{array}$ & 6 & 7 & 9 & 12 & $\begin{array}{c}7.50 \\
(62.5 \%)\end{array}$ & 2.26 \\
\hline \multicolumn{5}{|c|}{ Five-Number Summary of DC-Pretest-Posttest } & \multirow[b]{2}{*}{ Mean } & \multirow[b]{2}{*}{$\begin{array}{l}\text { Standard } \\
\text { deviation }\end{array}$} \\
\hline Min & $\begin{array}{l}\mathbf{1}^{\text {st }} \\
\text { Quartile }\end{array}$ & Median & $\begin{array}{c}3^{\text {rd }} \\
\text { Quartile }\end{array}$ & Max & & \\
\hline STEM $^{1}$ & 6 & 8 & 10 & 16 & $\begin{array}{c}8.375 \\
(52.34 \%)\end{array}$ & 2.72 \\
\hline $\begin{array}{l}\text { Non-STEM }{ }^{1} \\
0\end{array}$ & 5 & 7 & 9 & 14 & $\begin{array}{l}7.19 \\
(44.94 \%)\end{array}$ & 2.6 \\
\hline $\begin{array}{l}\text { STEM }^{2} \\
1\end{array}$ & 6 & 8 & 10 & 12 & $\begin{array}{l}6.26 \\
(39.13 \%)\end{array}$ & 2.65 \\
\hline $\begin{array}{l}\text { NonSTEM }^{2} \\
1\end{array}$ & 4 & 6 & 7 & 15 & $\begin{array}{l}5.83 \\
(36.44 \%) \\
\end{array}$ & 2.24 \\
\hline
\end{tabular}

Section 2.3: Comparison of 1-2 Year College Students and 3-4 Year College Students

This section displays the five number summary, class mean, class standard deviation and number of students of pretest and posttest for Year 12 students and Year 3-4 students respectively. It also shows the differences of pretest mean and posttest mean in each category of the test (see Table 4 and 5). 
Table 4: Summary of Pretest and Posttest for 1-2 Year 3-4 Year College Students.

\begin{tabular}{|c|c|c|c|c|c|c|c|c|}
\hline \multirow[b]{2}{*}{ Name } & \multicolumn{5}{|c|}{ Five-Number Summary-Total } & \multirow[b]{2}{*}{ Mean } & \multirow{2}{*}{$\begin{array}{l}\text { Standard } \\
\text { deviation }\end{array}$} & \multirow[b]{2}{*}{$N$} \\
\hline & Minimum & $\begin{array}{l}\mathbf{1}^{\text {st }} \\
\text { Quartile }\end{array}$ & Median & $\begin{array}{l}3^{\text {rd }} \\
\text { Quartile }\end{array}$ & Maximum & & & \\
\hline Pre-1,2 & 0 & 17 & 19 & 23 & 35 & 19.45 & 5.66 & 246 \\
\hline Pos-1,2 & 9 & 16 & 19 & 22 & 38 & 20.09 & 5.60 & 149 \\
\hline Pre-3,4 & 12 & 18 & 20 & 22 & 32 & 20.16 & 3.48 & 141 \\
\hline Pos-3,4 & 10 & 15 & 19 & 22 & 33 & 19.10 & 4.66 & 105 \\
\hline \multirow{2}{*}{ Name } & \multicolumn{5}{|c|}{ Five-Number Summary-RA } & \multirow[b]{2}{*}{ Mean } & \multirow{2}{*}{$\begin{array}{l}\text { Standard } \\
\text { deviation }\end{array}$} & \multirow[b]{2}{*}{$N$} \\
\hline & Minimum & $\begin{array}{l}\mathbf{1}^{\text {st }} \\
\text { Quartile }\end{array}$ & Median & $\begin{array}{l}3^{\text {rd }} \\
\text { Quartile }\end{array}$ & Maximum & & & \\
\hline Pre-1,2 & 0 & 4 & 5 & 7 & 12 & 5.52 & 2.69 & 246 \\
\hline Pos- 1,2 & 1 & 4 & 6 & 8 & 12 & 6.29 & 2.64 & 149 \\
\hline Pre-3,4 & 0 & 4 & 5 & 7 & 12 & 5.15 & 2.50 & 141 \\
\hline Pos-3,4 & 1 & 3 & 5 & 8 & 11 & 5.46 & 2.62 & 105 \\
\hline \multirow[b]{2}{*}{ Name } & \multicolumn{5}{|c|}{ Five-Number Summary-EA } & \multirow[b]{2}{*}{ Mean } & \multirow{2}{*}{$\begin{array}{l}\text { Standard } \\
\text { deviation }\end{array}$} & \multirow[b]{2}{*}{$N$} \\
\hline & Minimum & $\begin{array}{l}1^{\text {st }} \\
\text { Quartile }\end{array}$ & Median & $\begin{array}{l}3^{\text {rd }} \\
\text { Quartile }\end{array}$ & Maximum & & & \\
\hline Pre-1,2 & 0 & 5 & 7 & 8 & 11 & 6.38 & 2.01 & 246 \\
\hline Pos-1,2 & 3 & 6 & 7 & 10 & 12 & 7.66 & 2.29 & 149 \\
\hline Pre-3,4 & 2 & 6 & 7 & 9 & 10 & 6.92 & 1.88 & 141 \\
\hline Pos-3,4 & 1 & 6 & 8 & 9 & 12 & 7.79 & 2.22 & 105 \\
\hline \multirow[b]{2}{*}{ Name } & \multicolumn{5}{|c|}{ Five-Number Summary-DC } & \multirow[b]{2}{*}{ Mean } & \multirow{2}{*}{$\begin{array}{l}\text { Standard } \\
\text { deviation }\end{array}$} & \multirow[b]{2}{*}{$N$} \\
\hline & Minimum & $\begin{array}{l}\mathbf{1}^{\text {st }} \\
\text { Quartile }\end{array}$ & Median & $\begin{array}{l}3^{\text {rd }} \\
\text { Quartile }\end{array}$ & Maximum & & & \\
\hline Pre-1,2 & 0 & 6 & 7 & 9 & 16 & 7.54 & 2.85 & 246 \\
\hline Pos-1,2 & 1 & 4 & 6 & 8 & 15 & 6.14 & 2.58 & 149 \\
\hline Pre-3,4 & 3 & 7 & 8 & 10 & 13 & 8.10 & 1.92 & 141 \\
\hline Pos-3,4 & 1 & 4 & 6 & 7 & 13 & 5.85 & 2.17 & 105 \\
\hline
\end{tabular}

Table 5: Comparison of Pretest Mean and Posttest Mean for 1-2 Year 3-4 Year College Students.

\begin{tabular}{|l|l|l|l|}
\hline & Pretest Mean (Total) & Posttest Mean (total) & Difference \\
\hline Year 1-2 & $48.6 \%$ & $20.2 \%$ & $1.6 \% \nearrow$ \\
\hline Year 3-4 & $50.4 \%$ & $47.8 \%$ & $2.6 \% \searrow$ \\
\hline & Pretest Mean (RA) & Posttest Mean (RA) & Difference \\
\hline Year 1-2 & $46 \%$ & $52.4 \%$ & $6.4 \% \nearrow$ \\
\hline Year 3-4 & $42.9 \%$ & $45.5 \%$ & $2.6 \% \nearrow$ \\
\hline & Pretest Mean (EA) & Posttest Mean (EA) & Difference \\
\hline Year 1-2 & $53.2 \%$ & $63.8 \%$ & $10.6 \% \nearrow$ \\
\hline Year 3-4 & $57.7 \%$ & $64.9 \%$ & $7.2 \% \nearrow$ \\
\hline & Pretest Mean (DC) & Posttest Mean (DC) & Difference \\
\hline Year 1-2 & $47.1 \%$ & $38.4 \%$ & $8.7 \% \searrow$ \\
\hline Year 3-4 & $50.6 \%$ & $36.6 \%$ & $16 \% \searrow$ \\
\hline
\end{tabular}

Note: Total means the total number of correct answers in Pretests and 
Posttests, RA represents the category of Recognize Assumptions, EA stands for the category of Evaluate Arguments, and DC is the category of Draw Conclusion.

Comparison of 1-2 Year College Students and 3-4 Year College Students. As shown in Table 4 and 5 , there is a slight increase for 1-2 year students, but a noticeable decrease for 3-4 year college students comparing posttest mean with pretest mean. Students from Year 1 and 2 had a 6.4\% increase in the categories of Recognize Assumptions compared with a 2.6\% increase for Year 3 and 4 students. The increase of Year 1 and 2 is more than doubled of the increase for Year 3 and 4 students. In the category of Evaluate Arguments, there exists a $10.6 \%$ and $7.2 \%$ increase for Year 1-2 and 3-4 students respectively. For all students, it has a relatively large increase in this category. Both Year 1-2 and 3-4 students showed a decrease in the category of Draw Conclusions, while the rate of decrease for Year 1-2 students is only half of the rate for Year 3-4 students.

\section{Conclusion and Future Projects}

For all student participants, there is only slight difference between Pretests-total and Posttests-total. There is a noticeable increase in the categories of Recognize Assumptions and Evaluate Arguments and a relatively large decrease in the category of Draw Conclusions. For 1-2 year college students, there is a relatively large increase in Posttest means compared with Pretest means, while there is a decrease in the posttest means for 3-4 year college students. As for the analysis of each individual faculty member, $41 \%$ has an increase in Posttest means compared with the Pretest means. Compared with Non-STEM majors, STEM majors did slightly better in both Pretests and Posttests. There is only slight difference between pretest means and posttest means for both STEM and Non-STEM majors. In general, students from Non-STEM majors benefits more from teaching with technology than those in STEM majors.

The targeted student groups for future projects, which aim at increasing critical thinking through technology, should be 1-2 year college students and the outcomes of the tests should be related to extra credits in the course for student engagement. A pretest and posttest on the course content along with Critical Thinking test should be given at the beginning and the end of semester. Data should be collected under Baseline Condition (without using technology in teaching) and Experimental Condition (with technology in teaching) separately.

\section{Acknowledgement}

This work was supported by Fisk University Implementation Award sponsored by the National Science Foundation through NSF HRD 1332284 
and Elizabeth City State University MSEIP funded by Department of Education Award \# P120A110105.

\section{References:}

Allen, R. D. (1981). Intellectual Development and the Understanding of Science: Applications of William Perry's Theory to Science Teaching. Journal of College Science Teaching, 11 (2), 94-97.

Arons, A. B. (1985). Critical Thinking' and the Baccalaureate Curriculum. Liberal Education, 71 (2), 141-157.

Brouwer, P. (1996). Hold on a Minute Here: What Happened to Critical Thinking in the Information Age?, Journal of Educational Technology Systems, 25, 189-197.

McPeck, J. E. (1982). The Meaning of Critical Thinking. Canadian Journal of Education, 7 (4), 107-110.

Moll, M. B., and Allen, R. D. (1982). Developing Critical Thinking Skills in Biology, Journal of College Science Teaching, 4, 95- 98.

Dewey, J. (1910). How we think. Lexington, MA: D.C. Heath \& Company.

Reichenbach, B. (2000). An Introduction to Critical Thinking. Columbus, $\mathrm{OH}$ : Mcgraw Hill Higher Education.

Beyer, B. K. (1995). Critical Thinking. Bloomington, IN: Phi Delta Kappa Educational Foundation.

Paul, R. (2012). Critical Thinking: What Every Person Needs to Survive in a Rapidly Changing World. Tomales, CA: The Foundation for Critical Thinking. 